\title{
Frontal Projections of Dorsal Neck and Extraocular Muscles
}

\author{
B. O. DUBROVSKY AND H. BARBAS ${ }^{x}$ \\ $N$ euro physiological Laboratories, Allan Memorial Institute, and \\ Department of Physiology, McGill University, \\ Montreal,, Quebec, Canada
}

Received November 24,1976

\begin{abstract}
We investigated the projection sites of dorsal neck muscle afferents in cats anesthetized with chloralose urethane. Electrical stimulation of a nerve branch to the biventer cervicis and complexus, and nerve branches of the suboccipital nerve to the rectus capitis dorsalis major and to the obliquus capitis caudalis muscles evoked field and single-cell responses in frontal brain regions corresponding with frontal eye field regions in cats, at latencies of 6 to $15 \mathrm{~ms}$. By recording afferent volleys from dorsal rootlets of the first and second cervical segments, it was shown that neuronal activity in frontal brain regions could be elicited by signals from fibers electrophysiologically characterized as belonging to group I. Electrical stimulation of the nerve of the superior rectus muscle also elicited short-latency (6 to $20 \mathrm{~ms}$ ) field and single-cell activity in the frontal eye field regions. Moreover, a high degree of convergence was observed at the single-cell level between dorsal neck and extraocular muscle afferents. This convergence was significantly higher than the convergence observed between the rectus capitis dorsalis major and obliquus capitis caudalis (deep muscles) with the biventer cervicis and complexus muscles. The convergence of extraocular and dorsal neck muscle afferents onto frontal eye field regions isuggests an involvement of these cortical regions in mechanisms related with coordination of sequential eye-head movements.
\end{abstract}

\section{INTRODUCTION}

The dorsal neck muscles constitute an anatomically and functionally complex group of muscles $(23,46,47)$. Postural reflex responses of neck origin have been clearly established (48) and reflex responses of neck origin in extraocular muscles have been well known since their first obser-

\footnotetext{
${ }^{1}$ This work was. supported by the Medical Research Council, Ottawa, Canada. We thank Dr. Ronald Melzack for generous loan of instrumentation, Mr. Joel Tepper for technical support, and Mr. Pierre Vaillancourt for histological preparations.
}

680 
vation by Barany in 1907 (11). Experimental studies have disclosed that afferents from dorsal neck muscles project to various central brain areas $(1,2$, $6,17,18,28,54)$ and that in the superior colliculus (2) and in the nucleus prepositus hypoglossi (28) these afferents converge with visual and extraocular muscle afferents; this suggests an involvement of these regions in the control of coordinated eye-head movements. The possibility of afferent input from dorsal neck and extraocular muscles to frontal regions known to be involved in eye and head movement in cats $(29-31,50)$ has not received much specific attention as yet.

Neural mechanisms for coordination of eye-head movements were recently investigated in a series of experiments in seated, nonanesthetized monkeys, with their bodies restrained $(7,8,43)$. From these studies Bizzi concluded that "behavioral coordination of head and eyes is the joint result of a central initiation accompanied by the intervention of feedback from the periphery" (7). Those investigations also showed that in the paradigm used, which as far as the head was concerned involved only its rotation to the side, the vestibular system was the main source of peripheral feedback signals for the compensatory eye movements. Further, the work also revealed that during saccadic eye movements initiated while the head was in motion, signals from the neck region became a relevant control factor of these eye movements (43). Studies by Cohen (13) had previously shown that afferent discharges from neck receptors are essential for appropriate motor coordination during flexion and extension head movements, because signals from the neck are the primary source of information of the angle formed by the head and the body.

As is to be expected, the relative size of dorsal neck musculature varies considerably in different species (44) because animals hold their heads in different ways (15) ; this imposes variable demands on the neck muscles in terms of the force they need to generate to hold and move the head, and the peripheral feedback they must provide during combined eye-head movements. In man, the foramen magnum, through which the brain stem connects with the cerebral hemispheres, is situated in the middle of the base of the skull $(12,44$, 55). The fact that the atlantoccipital joint moved forward during the evolutionary process $(12,55)$ gave the dorsal neck muscles that insert in the lambdoidal ridge a long lever arm. This increased the turning effect of the force exerted by these muscles, so equilibrium of the head over the cervical spinal column could be maintained without great increase of the musculature size, a situation that would have hampered the necessary agility and mobility of the head (53).

On the other hand, in quadrupeds like the cat, the foramen magnum is in the posterior part of the skull, the lever arm of the dorsal neck muscles is much shorter, and the head is carried "upon projecting arm or cantilever" 
(53). In the latter condition, even small rotatory head movements produce shifts in the animal's center of gravity, shifts that elicit reflex postural adjustments (48).

Recent experimental work in animals $(21,40)$ and man (24) suggests that signals from extraocular muscles also exert a significant influence in postural mechanisms. These functional and evolutionary considerations led us to explore the possibility that dorsal neck and extraocular muscle affer-ents may project to frontal areas known to be related to eye-head movements in the cat.

Our results present evidence that activity elicited by electrical stimulation of afferents from dorsal neck muscles project to frontal regions corresponding with frontal eye field regions and converge at the single-cell level with afferents from extraocular muscles. The high density of receptors in both extraocular $(3,27)$ and dorsal neck muscles $(27,47)$, the currently recognized role of muscle receptors in kinesthesia (26), and the fact that muscle information can be utilized to control the activity of regard (34), suggest a role of these afferents in the control of sequentially organized coordinated eyehead movement.

\section{METHODS}

Experiments were done on 26 cats anesthetized with alpha chloralose $(60 \mathrm{mg} / \mathrm{kg}$, intravenous) dissolved in aqueous urethane solution. The trachea was intubated and the animal later paralyzed with gallamine triethi-odide (Flaxedil) $(8 \mathrm{mg} / \mathrm{kg}$, intravenous) and artifically respired. The femoral artery was cannulated and blood pressure continuously monitored and kept between 110 and ISO mm Hg with physiological solutions when necessary. The femoral vein was also cannulated for infusion of additional anesthetic agent ( $10 \%$ of the original dose every $4 \mathrm{~h}$ ), Flaxedil, and maintaining solutions. The temperature was kept at physiological range $\left(37\right.$ to $\left.38^{\circ} \mathrm{C}\right)$, with a dc heating pad. A nerve branch innervating the biventer cervicis and complexus and branches of the suboccipital nerve to the rectus capitis dorsalis major and to the obliquus capitis caudalis were prepared for stimulation bilaterally. In 16 experiments the suboccipital nerve was prepared for stimulation by positioning electrodes just before the nerve branches to supply the suboccipital group of muscles: the rectus capitis major, medius, and minor, and the obliquus capitis caudalis, and cranialis. Nerve stimulation was bifocal through chlorided silver wires. The nerves and electrodes were covered with molten wax to insulate them from the surrounding tissues. Stimulation was delivered by a Grass 8 stimulator through a stimulus isolation unit.

To monitor the group of fibers activated, afferent volleys were recorded from dorsal rootlets of the first and second cervical segments. For this pur- 


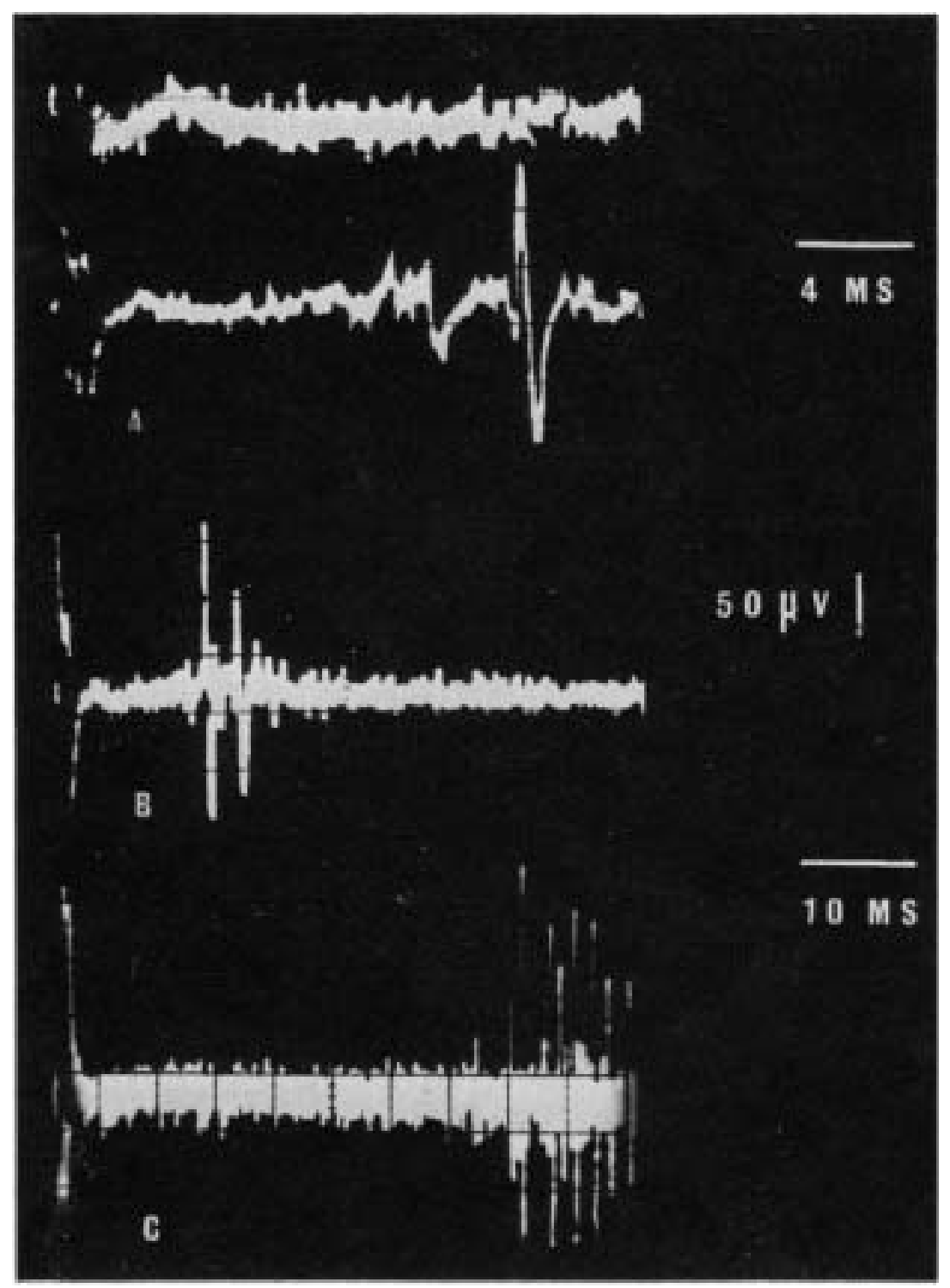

FIG. 1. A-Cell response in presylvian region to threshold electrical stimulation of the suboccipital nerve. Upper trace, afferent volley recorded from dorsal rootlets of the first cervical segment. B-Cell response in presylvian region to electrical stimulation (1.2 times threshold) of a nerve branch to the biventer cervicis and complexus muscles. C-Response in lower lip of the cruciate to electrical stimulation of the nerve of the superior rectus. All responses recorded contralateral to the stimulated side. 
pose two pieces of cotton thread moistened with physiological saline were placed around individual rootlets at the $\mathrm{Ci}$ and $C \%$ levels. The cotton threads were then immersed in two small plastic containers filled with physiological saline with a coil of chlorided silver wire acting as the interface connection with the amplification system. Evoked potentials were amplified through a 122 Tektronix preamplifier set at a time constant of $1 \mathrm{~s}(0.2-\mathrm{Hz}$ frequency response) for the low-frequency components of the response, and at $10 \mathrm{k} \mathrm{Hz}$ for the highfrequency components. This system enabled recording from a discrete population of the afferents with great stability and reliability. The stimulation required to elicit detectable activity in the rootlets was taken as the threshold intensity to activate group I fibers from the stimulated nerve. However, due to overlaps in electrical threshold for groups la and $\mathrm{Ib}(32)$ and between $\mathrm{Ib}$ and group II (22), no specific statement can be made on the type of receptors from where the activated fibers originated. Strength of applied stimuli was expressed as a multiple of the reference threshold value. Currents of $300 / / \mathrm{A}$ for 0.030 to $0.050 \mathrm{~ms}$ were usually sufficient to elicit detectable activity in the first and second rootlets. Occasionally train stimulation (three pulses of $0.25 \mathrm{~ms}, 1-\mathrm{ms}$ total burst duration) was also used to activate nerve fibers.

The branch of the oculomotor nerve which innervates the superior rectus, an extrinsic eye muscle, was also dissected and prepared for stimulation contralateral to the recording site.

TABLE 1

Number of Responsive Units in Pericruciate and Presylvian Regions to Stimulation of Dorsal Neck and Extrinsic Eye Muscle Nerves

$$
\begin{gathered}
\text { Muscle nerve } \\
\text { stimulated }
\end{gathered}
$$

\footnotetext{
Contralateral biventer cervicis/complexus Ipsilateral biventer cervicis/complexus Contralateral suboccipital or branches to rectus capitis dorsalis major or obliquus capitis caudalis

Contralateral superior rectus
}

\begin{tabular}{clc}
$\begin{array}{c}\text { Number Number } \\
\text { of units of respon- } \\
\text { tested sive units }\end{array}$ & \multicolumn{2}{c}{ Distribution of responsive units } \\
& $\begin{array}{l}\text { Upper Lower } \\
\text { cruciate cruciate } \\
\text { cortex cortex }\end{array}$ & $\begin{array}{c}\text { Presylvian } \\
\text { cortex }\end{array}$ \\
\hline
\end{tabular}

$\begin{array}{ccccc}216 & 182 & 54 & 75 & 53 \\ 98 & 58 & 20 & 25 & 1 \\ & & & & \\ 92 & 46 & 7 & 9 & 30 \\ 88 & 54 & 1 & 41 & 3\end{array}$


The anterior brain area was exposed unilaterally, and drying was prevented by constant dripping of warm mineral oil over the cortex. Recordings were made with glass-covered tungsten microelectrodes connected through a cathode follower and amplified for display on a cathode ray oscilloscope. A storage oscilloscope served as slave from which photographs were taken.

Systematic explorations of evoked neural activity in response to stimulation of the nerves of dorsal neck and extraocular muscles were made in the frontal cortex. The explored regions extended between $2 \mathrm{~mm}$ anterior of the cruciate sulcus to $3.5 \mathrm{~mm}$ posterior of the cruciate, 1 to $9 \mathrm{~mm}$ lateral from the midline, and to $9 \mathrm{~mm}$ deep. Electrolytic lesions produced by passing direct current (anode connected to the microelectrode) of 3 to $5 / / A$ for 3 to $5 \mathrm{~s}$ were made at various recording levels for reconstruction of recording tracts and histological identification of responsive sites.

After each experiment the animals were perfused through the heart with $10 \%$ formol saline. The brain was removed, fixed in formalin and embedded in celloidin. The explored regions were cut in $30 \mathrm{um}$ sections and were stained with cresyl violet for microscopic examination.

\section{RESULTS}

Field and single-cell activity was recorded in the postcruciate dimple in response to threshold electrical stimulation of the nerves of the biventer cervicis-complexus, and the suboccipital nerve or one of its branches to the rectus capitis dorsalis major and to the obliquus capitis caudalis muscles. These results are consistent with and extend earlier findings of Landgren and Silfvenius (35), who reported projections from group I afferents from the splenius, a dorsal neck muscle, to this region. The latency of evoked neural activity to this locus was $6 \pm 2 \mathrm{~ms}$.

Rostral to the area of the postcruciate dimple, responses of 210 neurons to stimulation of dorsal neck muscle nerves were studied in 52 penetrations. Out of these units, 182 responded to stimulation of the nerve of the biventer cervicis and complexus contralateral to the recording site (Fig. IB), 58 units responded to stimulation of the nerve of the same muscles ipsilateral to the recording site, and 46 responded to stimulation of the suboccipital nerve or its branches to the rectus capitis dorsalis major and obliquus capitis caudalis (Fig. 1A). These figures represent an $84 \%$ response for the contralateral biventer cervicis and complexus, a $59 \%$ response for the ipsilateral biventer cervicis and complexus, and a 50\% response for the suboccipital group. These results are summarized in Table 1.

Of 87 cells tested, 45 responded to stimulation of both the contralateral and ipsilateral nerve branch to the biventer cervicis and complexus, and convergence between the afferents from the biventer cervicis and complexus 
Convergence of Dorsal Neck and Extraocular Muscle Afferents in Pericruciate and Presylvian Regions

Muscle nerves stimulated

\begin{tabular}{lc}
$\begin{array}{l}\text { Number of } \\
\text { units tested } \\
\text { convergence }\end{array}$ & $\begin{array}{c}\text { Number of } \\
\text { units showing }\end{array}$ \\
\hline
\end{tabular}
convergence

Contralateral biventer cervicis/complexus and ipsilateral biventer cervicis/complexus

Contralateral biventer cervicis/complexus and contralateral suboccipital or branches to rectus capitis dorsalis major or obliquus capitis caudalis

Contralateral biventer cervicis/complexus and contralateral superior rectus

Contralateral suboccipital or branches to rectus capitis dorsalis major or obliquus capitis caudalis and Contralateral superior rectus

17
424
43

muscles with the suboccipital group of muscles was observed in 17 out of 82 cells (see Table 2).

Examination of recording sites responsive to stimulation of dorsal neck muscle nerves in these penetrations showed a double distribution. One of these included the upper and lower lip of the cruciate sulcus. The other site encompassed the bottom and both margins of the presylvian sulcus. Figure 2 is a series of composite maps reconstructed from histological examination of coronal sections of the frontal pole of the brain, showing the responsive sites.

Sites responsive to stimulation of the Contralateral nerves of the suboccipital group of muscles were mainly concentrated in presylvian regions, whereas the sites responsive to stimulation of the Contralateral nerve of the biventer cervicis and complexus extended within both responsive loci. Of 44 cells which responded to threshold stimulation of dorsal neck muscle nerves, 30 were situated in presylvian and 14 in pericruciate regions. However, for $75 \%$ of the 210 cells studied, intensities of 1.1 to 1.3 times threshold were necessary to obtain responses and latencies were longer, 15 to $35 \mathrm{~ms}$ (Figs. 3A, 4A).

The latencies of responses within the presylvian regions were characteristically short (6 to $15 \mathrm{~ms}$ ). The longest latencies $(30$ to $50 \mathrm{~ms})$ were obtained at the upper lip of the cruciate gyrus, with the latencies being shorter as the microelectrode advanced deeper. The relationship between recording site and latency is shown in Fig. 5.

Field and single-cell activity in response to Contralateral stimulation of dorsal neck muscle afferents followed frequencies up to $2 / \mathrm{s}$. This finding is 

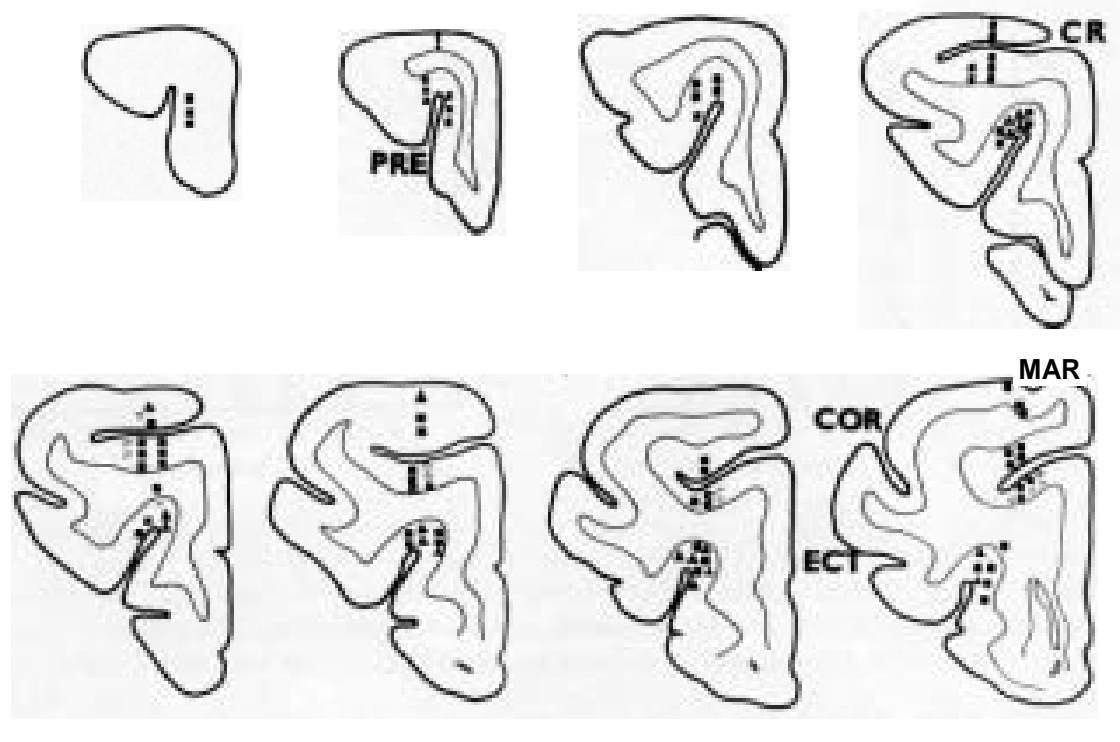

FIG. 2. Distribution of responses evoked in frontal regions of the cat brain by electrical stimulation of afferents from dorsal neck muscles. B-Responses to stimulation of nerve branch to the biventer cervicis and complexus muscles. A-Responses to stimulation of afferents from suboccipital muscles. O-Responses to stimulation of afferents from the nerve to the superior rectus muscle; all contralateral to the recording site. CR, cruciate sulcus; COR, coronal sulcus; MAR, marginal sulcus; PRE, presylvian sulcus; and ECT, ectosylvian sulcus.

consistent with the frequency response of lateral eye movement stabilization by neck proprioceptors (41). Responses to ipsilateral stimulation had longer latencies compared to contralateral ones (Fig. 3B), and could only follow consistently frequencies of $0.5 / \mathrm{s}$ or less.

Current work in our laboratory indicates that, although not the exclusive pathway for transmission of dorsal neck muscle afferent signals to higher brain centers, the dorsal columns appear to be essential for the transmission of signals from low-threshold afferent fibers from these muscle groups to frontal brain regions.

Single-unit and field responses were also found to arrive at the frontal eye field regions in response to stimulation of the branch of the oculomotor nerve which supplies the superior rectus (Fig. 1C). Of 88 cells tested, 54 responded to stimulation of the contralateral superior rectus nerve. The response latencies of these units were between 6 and $40 \mathrm{~ms}$, as shown in Fig. 4B. Of these 54 responsive units, 48 showed convergence with dorsal neck muscle afferents. Forty-four of these units converged with afferents 

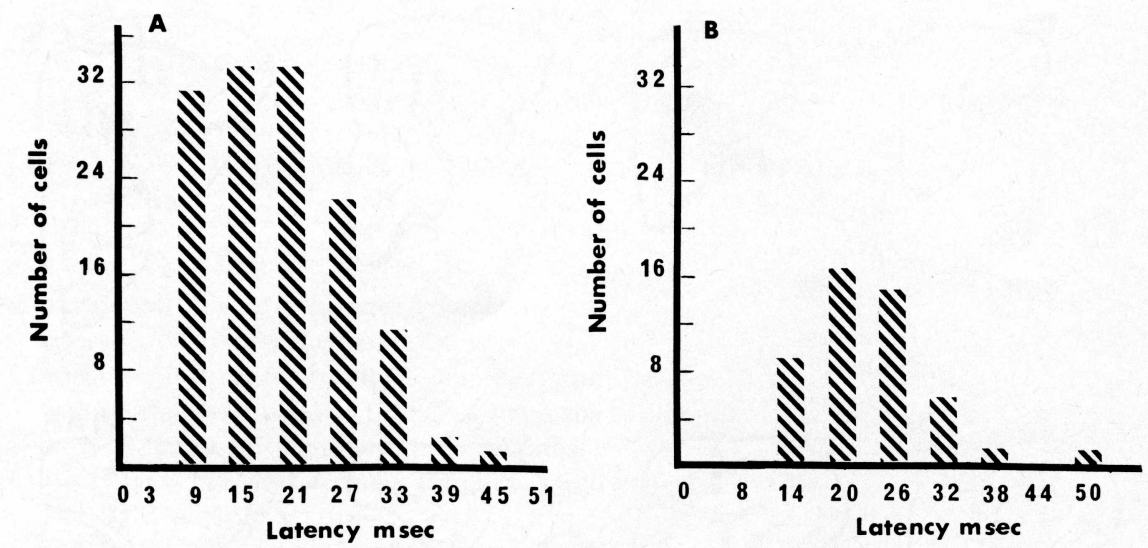

FIG. 3. Interval histogram illustrating the distribution of the response latency of neurons in pericruciate and presylvian cortical regions after electrical stimulation of afferents from a nerve branch innervating the biventer cervicis and complexus muscles; contralateral $\mathrm{A}$, and ipsilateral $\mathrm{B}$, to the recording site. The numbers along the abscissae (as in Figs. 4 and 5) indicate the midpoint of each latency interval.

from the biventer cervicis and complexus, and 13 converged with afferents from the suboccipital group of neck muscles. The convergence between dorsal neck afferents and eye muscle afferents was higher than that observed between the biventer cervicis-complexus and the suboccipital muscle nerve afferents.

Histological inspection revealed that the majority $(76 \%)$ of neurons responding to stimulation of superior rectus afferents were at the lateral zone of the lower lip of the cruciate sulcus, a region which also receives
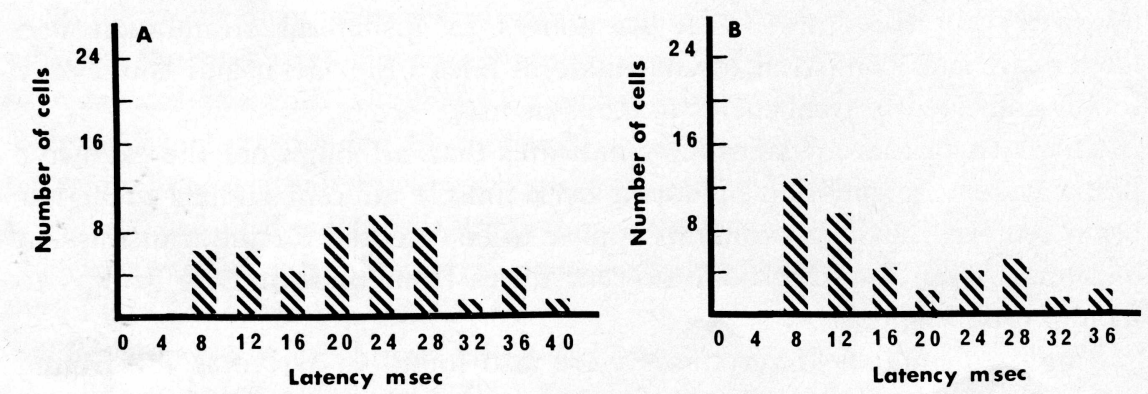

FIG. 4. A-Latency distribution intervals of neuronal responses in pericruciate and presylvian cortex to stimulation of afferents from the suboccipital nerve or its branches to the rectus capitis major and obliquus capitis caudalis muscles. B-Latency distribution intervals of neuronal responses in pericruciate and presylvian cortical regions to stimulation of the nerve of the superior rectus muscle; $\mathrm{A}$ and $\mathrm{B}$ both contralateral to the recording site. 
afferents from the biventer cervicis and complexus and the suboccipital group of muscles (Fig. 2). The other neuron responses were distributed in the margins of the presylvian sulcus and the pericruciate cortex (see Table 1).

\section{DISCUSSION}

The results of the present experiments showed that electrical stimulation of low-threshold afferents from dorsal neck muscles as well as afferents from extraocular muscles evoked field and single-cell activity in frontal regions of the brain. It has been shown by lesion and stimulation experiments that regions in the frontal pole, namely the lower lip of the cruciate and the bottom and both margins of the presylvian gyrus, are associated with eyehead movements $(29,31,50)$. Lesions of these regions result in transient persistence of gaze in the cat $(16,33)$ and the monkey $(36)$, and in deficits in anticipatory visual attending and visual search in the cat (49) and the monkey (37), respectively. In the nonanesthetized unrestrained cat, electrical stimulation of these regions results in coordinated eye-head movement $(29,31)$. Such stimulation produces eye movements in the "encephale isolee" preparation with the head fixed (50).

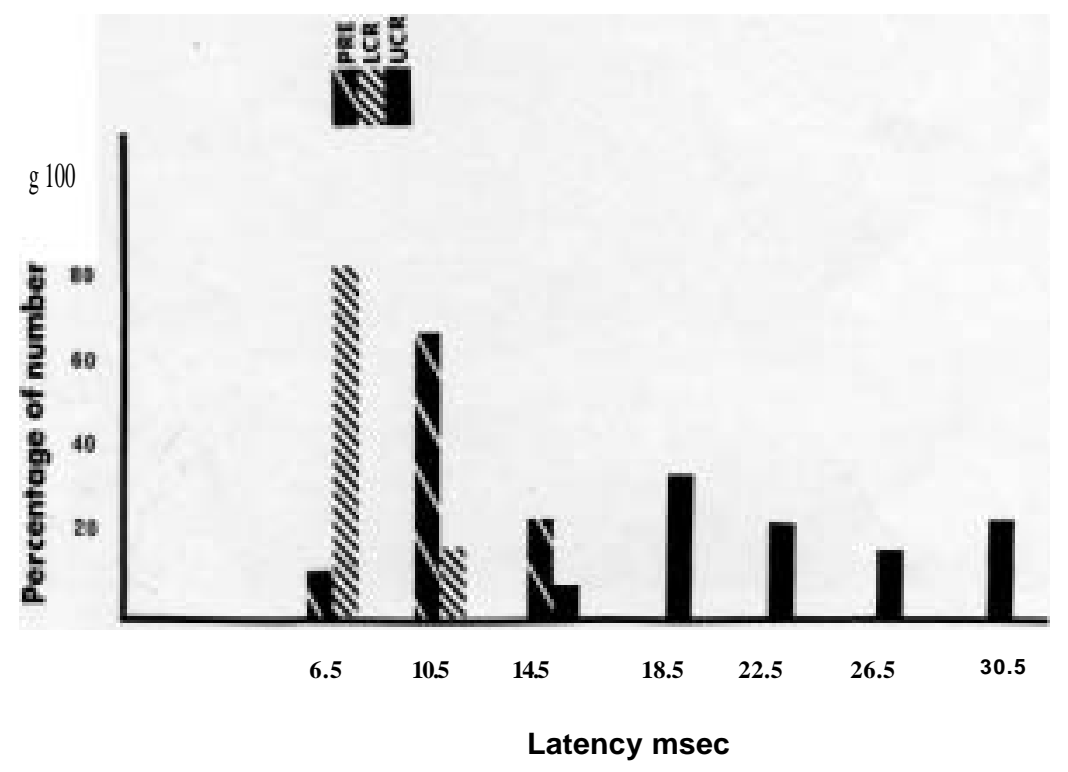

FIG. 5. Histogram showing the latency distribution intervals in different zones of the frontal lobe of neurons responding to stimulation of dorsal neck muscles. UCR - upper lip of cruciate sulcus, LCR-lower lip of the cruciate sulcus, and PRE—-presylvian regions. 
Experimental evidence indicates that when only the eyes move for fixation or foveation, they move in reference to a coordinate system locked to visual space and not to the head (14). Coordinated eye-head movement, however, must operate in a system that takes into account the position of the head in relation to the body and the position of the eyes in their orbits $(7,38)$. The present results showed convergent input from extraocular and dorsal neck muscle afferents at the single-cell level within the frontal eye field at latencies as short as 6 to 10 $\mathrm{ms}$. The interaction of eye and neck muscle signals in this region may be a step in the sensory-motor integration necessary for eye-head coordination.

In cases where the eyes are not centered in their orbits at the beginning of a combined eye-head movement, information concerning eye position $(3,52)$ and access of the retinal error signal to the motor control system of both the head and the eyes become prerequisite for appropriate eye-head coordination $(7,38$, 45). It may be noted in this context that anatomical (4) and physiological (40) results show that sensory afferents from extraocular muscles project to the trigeminal nucleus in the brain stem and that trigeminal afferents involving the orbital region project to frontal brain regions (39) overlapping with those described in this work. Recently, it was also shown that electrical stimulation of trigeminal afferents elicits electromyographic activity in extraocular muscles in man (10).

The present investigation also showed that dorsal neck muscle afferents project to two different loci. One involved regions of the pericruciate and the other the presylvian cortex. The latency responses within the presylvian fields were significantly shorter than those observed in pericruciate regions.

Recently, Guitton and Mandl (30), recording from nonanesthetized cats, observed that cells in these regions discharge in association with and/or preceding activity in the biventer cervicis, a dorsal neck muscle. The polymodal characteristics of response, as well as the somatotopic arrangement and topographical organization of visual input to pericruciate cortex neurons have been clearly established $(9,19,25,27)$. As it pertains to afferents from the dorsal neck muscles, our results show that the upper and lower lip of the cruciate sulcus received afferents mainly from dorsal neck muscles which extend across the cervical spine from origin to insertion. In the cat, the contraction of these muscles produces movements which deviate the cantilevered head from both the body axis and the gravitational axis; these two axes coincide in man but not in quadrupeds. Spinal cervical afferents which provide the brain with information about the angle formed by the head and the body (13) may be important in coordinated eye and head movements in cases where the head moves in relation to the body while the body is also in motion $(20,42)$. This task requires information from both the vestibular and dorsal neck systems. It has already been shown that ves- 
tibular (9) as well as visual (25) afferents project to frontal regions corresponding to the body axis. This study showed that the regions receiving dorsal neck and extraocular muscle afferents overlap with these frontal regions.

The two margins of the presylvian sulcus received projections from both the more superficially and longitudinally extended, and the suboccipital groups of dorsal neck muscles. Contraction of the suboccipital group results in small head movements, and Granit (27) has suggested that these muscles can play an important role in head stabilization, a necessary condition for appropriate function of the distance receptors (51). Those results and the difference in latencies, shorter in presylvian than in pericruciate zones, suggest that presylvian fields may be involved, although not exclusively, with fine control of head position (30).

The evidence presented showed that proprioceptive signals from dorsal neck and extraocular muscles project and converge in frontal regions of the brain in cats. We suggest that these signals, in conjunction with input from visual (25) and vestibular (9) systems also arriving at these regions, are of importance for coordination of eye-head movements and for the establishment of space representation in the central nervous system which is a prerequisite for the execution of movements directed to the outside world $(5,19,25,38,45)$.

\section{REFERENCES}

1. ABRAHAMS, V. C. 1970. Cervico-lumbar reflex interactions involving a proprioceptive receiving area of the cerebral cortex. /. PhysioL (London) 209: 45-56.

2. ABRAHAMS, V. C., AND P. K. ROSE. 1975. Projections of extraocular, neck muscle, and retinal afferents to superior colliculus in the cat: their connections to cells of origin of tectospinal tract. /. Neurophysiol. 38: 10-18.

3. BACH-Y-RITA, P., AND F. ITO. 1966. Properties of stretch receptors in cat extra-ocular muscles. /. PhysioL (London) 186: 663-688.

4. BATINI, C., P. BUISSERET, AND C. BUISSERET-DELMAS. 1975. Trigeminal pathway of the extrinsic eye muscle afferents in cats. Brain Res. 85: 74-78.

5. BERNSTEIN, N. 1967. The Co-ordination and Regulation of Movements. Pergamon Press, London.

6. BERTHOZ, A., AND R. LLINAS. 1974. Afferent neck projections to the cat cere-bellar cortex. Exp. Brain Res. 20: 385-401.

7. BIZZI, . E. 1975. Motor coordination: central and peripheral control during eye-head movement. Pages 427-437 in M. GAZZANIGA AND C. BLACKMORE, Eds., Handbook of Psychobiology. Academic Press, New York.

8. BIZZI, E., R. E. KALIL, P. MORASSO, AND V. TAGLIASCO. 1972. Central programming and peripheral feedback during eye-head coordination in monkeys. Bibl. Ophthalmol. 82: 220-232.

-9. BoiSACQ-ScHEFENs, N., AND M. Roucoux-HANUS. 1975. Responses of motor cortex cells to tilt in the "encephale isole" cat. Brain Res. 92: 149-152. 
10. BRATZLAVSKY, M., AND H. VANDER-EECKEN. 1975. A trigeminoabducens reflex in man. Exp. Nenrol 49: 336-338.

11. CAMIS, M. 1930. The Physiology of the Vestibular Apparatus. Clarendon Press, Oxford.

12. CLARK-LE GROS, W. E. 1965. A History of Primates. British Museum, London.

13. COHEN, L. 1961. Role of eye and neck proprioceptive mechanisms in body orientation and motor coordination. /. Neurophysiol. 24: 1-11.

14. COLlEwiJn, H. 1975. Oculomotor areas in the rabbit's midbrain and pretectum. /. Neurobiol. 6: 3-22.

15. DE BEER, G. R. 1947. How animals hold their heads. Proc. Linn. Soc. London 159: 125-139.

16. DREHER, B., AND B. ZERNICKI. 1969. Studies on the visual fixation reflex. III. The effects of frontal lesions in the cat. Acta Neurobiol. Exp. 30: 69-77.

17. DUBROVSKY, B. 1974. Cerebral and cerebellar projections from neck muscles in cats. Proc. Int. Union Physiol. Sci. XI: 182.

18. DUBROVSKY, B., AND H. BARBAS. 1975. Central projections of dorsal neck muscles. Neurosci. Abst. 1: 234.

19. DUBROVSKY, B., AND E. GARCIA-RILL. 1971. Convergence of tectal and visual input in cat motorsensory cortex. Exp. Neurol. 33: 475-484.

20. DUBROVSKY, B., AND E. GARCIA-RILL. 1973. Role of dorsal columns in sequential motor acts requiring precise forelimb projection. Exp. Brain Res. 18: 165-177.

21. EASTON, T. A. 1972. Patterned inhibition from single eye muscle stretch in the cat. Exp. Neurol. 34: 497-510.

22. ECCLES, R. M., AND A. LUNDBERG. 1959. Synaptic actions in motoneurons by afferents which may evoke the flexion reflex. Arch. Ital. Biol. 97: 199-221.

23. ELLIOTT, R. 1934. Anatomy of the Cat. 3rd ed., J. REIGHARD AND M. S. JENNINGS, Eds. Holt, Rinehart and Winston, New York. Reprinted 1961.

24. GANTCHEV, G., S. DUNEV, AND N. DRAGANOVA. 1973. On the spontaneous and induced body oscillations. Pages 179-194 in A. GYDICOV, N. TANKOV, AND D. KOSAROV, Eds., Motor Control. Plenum Press, New York and London.

25. GARCIA-RILL, E., AND B. DUBROVSKY. 1973. Topographical organization of visual input to precruciate cortex of cat. Brain Res. 56: 151-163.

26. GOODWIN, G. M., D. I. MCCLOSKEY, AND P. B. C. MATTHEWS. 1972. The contribution of muscle afferents to kinaesthesia shown by vibration induced illusions of movement and by the effects of paralysing joint afferents. Brain 95: 705-748.

27. GRANIT, R. 1970. The Basis of Motor Control. Academic Press, London and New York.

28. GRESTY, M., AND R. BAKER. 1976. Neurons with visual receptive field, eye movement and neck displacement sensitivity within and around the nucleus pre-positus hypoglossi in the alert cat. Exp. Brain Res. 24: 429-433.

29. GUITTON, D., AND G. MANDL. 1976. Frontal oculomotor area in alert cat: I. Eye movements and neck muscle activity evoked by stimulation. Brain Res.. In press.

30. GUITTON, D., AND G. MANDL. 1976. Frontal oculomotor area in alert cat: II. Unit discharges associated with eye movements and neck muscle activity. Brain Res. In press.

^_,31. HASSLER, R. 1966. Extrapyramidal motor areas of cat's frontal lobe: their functional and architectonic differentiation. Int. J. Neurol. 5: 301-306.

32. JACK, J. J. B., AND C. R. MACLENNAN. 1971. The lack of an electrical threshold discrimination between group 1A and group IB fibers in the nerve to the cat peroneus longus muscle. /. Physiol. (London) 212: 35-36.

33. JEANNEROD, M., S. KIYONO, AND J. MOURET. 1968. Effets des lesions, frontales 
bilaterales sur le comportement oculo-moteur chez le chat. Vision Res. 8: 575583.

34. LACKNER, J. R. 1975. Pursuit eye movements elicited by muscle afferent information. Neurosci. Letters 1: 25-28.

35. LANDGREN, S., AND H. SILFVENIUS. 1968. Projections of the eye and the neck region on the anterior suprasylvian cerebral cortex of the cat. Ada Physiol. Scand. 74: 340347.

36. LATTO, R., AND A. COWEY. 1972. Frontal eye field lesions in monkeys. Bibl. Ophthalmol. 82: 159-168.

37. LATTO, R., AND S. IVERSEN. 1973. Visual search in monkeys: the effects of frontal eyefield, inferior parietal and superior collicular lesions. Brain Res. 49: 507.

38. LUDVIGH, E. 1952. Control of ocular movements and visual interpretation of environment. Arch. Ophthalmol. 48: 442.

39. LUND, J., AND B. SESSLE. 1974. Oral facial and jaw muscle afferent projections to neurons in cat frontal cortex. Exp. N enrol. 45: 314-331.

40. MANNI, E., G. PALMIERI, R. MARINI, AND V. E. PETOYOSSI. 1975. Trigeminal influences on extensor muscles of the neck. Exp. N enrol. 47: 330-342.

41. MEIRY, J. L. 1971. Vestibular and proprioceptive stabilization of eye movement. Pages 483-496 in P. BACH-Y-RITA, C. COLLINS, AND J. E. HYDE, Eds., The Control of Eye Movements. Academic Press, New York.

42. MitTElstAedT, H. 1964. Basic control patterns of orientation homeostasis. Symp. Soc. Exp. Biol. 18: 365-385.

43. MORASSO, P., E. BIZZI, AND J. DICHGANS. 1973. Adjustment of saccade characteristics during head movements. Exp. Brain Res. 16: 492-500.

44. NAPIER, J. 1970. The Roots of Mankind. Smithsonian Institution Press, Washington, D.C.

45. PAILlARD, J., AND D. BEAUBATON. 1976. Triggered and guided components of visual reaching. Their dissociation in split-brain studies. Pages 333-347 in M. SHAHANI, Ed., The Motor System: N euro physiology and Muscle Mechanisms. Elsevier, Amsterdam.

46. RICHMOND, F. J. R., AND V. C. ABRAHAMS. 1975. Morphology and enzyme histochemistry of dorsal muscles of the cat neck. /. Neurophysiol. 38: 1312-1321.

47. RICHMOND, F. J. R., AND V. C. ABRAHAMS. 1975. Morphology and distribution of muscle spindles in dorsal muscles of the cat neck. /. Neurophysiol. 38: 1322-1339.

•48. ROBERTS, T. D. M. 1967. N euro physiology of Postural Mechanisms. Butter worths, London.

49. SCHLAG-REY, M., AND D. B. LINDSLEY. Effects of prefrontal lesions on trained anticipatory visual attending in cats. Physiol. Behav. 5: 1033-1041.

50. SCHLAG, J., AND M. SCHLAG-REY. 1970. Induction of oculomotor responses by electrical stimulation of the prefrontal cortex in the cat. Brain Res. 22: 1-13.

51. SHERRINGTON, H. S. 1906. The Integrative Action of the Nervous System. Yale University Press, New Haven.

52. SKAVENSKI, A. A. 1971. Inflows as a source of extraretinal eye position information. Vision Res. 12: 221-229.

53. THOMPSON, D. W. 1917. On Growth and Form. Abridged edition, J. T. BONNER, Ed., University Press, Cambridge, 1961.

54. WILSON, V. J., M. MAEDA, AND J. K. FRANK. 1975. Input from neck afferents to the cat flocculus. Brain Res. 89: 133-138.

55. YOUNG, J. Z. 1974. An Introduction to the Study of Man. Oxford University Press, London. 